\title{
Metadrama and the Deconstruction of Stereotypes: David Henry Hwang's M. Butterfly and Bondage
}

\author{
Haris Abdulwahab Fayez Noureldin*
}

Song: I'm an artist, Rene. You were my greatest ... acting challenge.

(She laughs.)

(M. Butterfly 63) ${ }^{l}$

Song: But no. Men. You're like the rest of them. It's all in the way we dress, and make up our faces and bat our eyelashes. You really have so little imagination!

(M. Butterfly 90)

Representations of Asians in America have always been influenced by biased stereotypical images. According to James S. Moy, "Anglo-American playwrights have portrayed the Chinese in America as collections of fetishized parts and as exotics" (48). Though there were other attempts seemingly providing positive images of the East as 'wise' in contrast with the West as 'corrupt', these attempts -Eugene O'Neill's Marco Millions is a striking examplecould do little more than present the East as 'exotic' and 'heathen'. With the rise of Asian-American studies in the 1960s, there appeared Asian writers, Chinese and Japanese, whose end goal was to dispel such stereotypes and present instead conscious self-representation. Notable among these is the Chinese-American playwright, David Henry Hwang (1957-), whose plays provide insightful explorations of how it feels to be Chinese or Asian in a racist society.

Regarded as "the most renowned Asian-American dramatist of the twentieth century" (Trudeau 199), Hwang distinguishes himself as a dramatist by blending Eastern and Western subjects and theatrical styles. The theme of the fluidity of identity is recurrent in almost all his plays. Hwang posits the changeability of a person's identity according to the various contacts s/he experiences. Hwang's plays include FOB (1980), The Dance and the Railroad (1981), Family Devotions (1981), Sound and Beauty (1983), Rich Relations (1986), M. Butterfly (1988), Bondage (1992), Trying to Find Chinatown (1996), and Yellow Face (2007), to mention but a few. These plays, particularly the several prizeswinning M. Butterfly, represent "far more contributions to ethnic theater;" they "provide brilliant and complex analyses of the politics of race, gender, class, and

\footnotetext{
* Department of English, Faculty of Languages (Al-Alsun), Aswan University.
} 
sexuality" (Bonnie 230). These plays mark Hwang's development as a playwright participating in the American cultural discourse. Roughly speaking, his early plays mark his position as a self-loathing immigrant who internalizes assimilationist tendencies. Hwang then moves forward to the isolationist phase in which his focus was on the re-telling of traditional Japanese stories. With $M$. Butterfly (1988), Hwang began to move center stage achieving prominence as an ethnic playwright tackling daring issues of the racial and gender power relations. In his other and recent plays, Hwang continues his theatrical outputs culminating in his interesting work Chinglish (2011) negotiating ethnic tensions and identity formation.

This paper contends that in his two plays M. Butterfly (1988) and Bondage (1992), Hwang utilizes metadramatic devices to deconstruct racial and gender stereotypes about minorities in America, particularly the Asians. Hwang's two plays are explicitly about de-naturalizing and de-essentializing the notion of the fixity of the racial and gender stereotypes. The titles of the target plays are signifiers of that theme. 'M Butterfly' is a reference to the Western cultural formation of the oriental woman, and, in fact, of the Orient at large. All the traditional feminine specificities of silence, obedience, weakness, vulnerability, inferiority, marginality is attached to the image of the butterfly. These identity markers are further used to define all Orientals, men and women, and the East in its relationship with the West. The title of the second play, Bondage, refers to, the bondage of slavery and all the associated binaries of the white and the black, the male and the female and the West and the East. The deconstruction of these binaries most probably leads to true intimacy between people and nations. These stereotypical images are negotiated in the target plays through a set of metadramatic devices moving the audience towards a realization of the vulnerability and invalidity of the biased cultural representations.

In Drama, Metadrama, and Perception, Richard Hornby defines metadrama as "a drama about drama" (31), suggesting that metadramatic texts yield their meanings through a system of relations and references. Each play, Hornby explains, "relates to other plays as a system" and "[t]his system, in turn, intersects with other systems of literature, non-literary performances, other art form (both high and low), and culture generally" (17). In other words, the metadramatic play is a composite of other texts from various disciplines of knowledge. These texts interact in a way producing layers of meanings depending on the richness of their original signification. The metadramatic play is thus highly introspective and self-reflective. 
Hornby classifies metadrama into five categories: 1) the play within the play; 2) ceremony within the play; 3 ) role-playing within the role; 4) literary and real life references; and 5) self-references (32). Although these five categories may exist separately, they could also, as is the case in Hwang's dramas, be blended and interwoven into the dramatic fabric of the play. 'The play within the play,' as Hornby explains, branches into two types: the inset type and the framed type. In the inset type, the inner play is integrated into the main action and is acknowledged by characters as a performance that they may interact with and evaluate. In the framed type, the inner play is the primary; the outer play, the frame. Liang Fei argues that the play within the play technique "is reflective and expressive of the playwright's or the audience's outlooks about life" (100). The device is mostly used as a metaphor for reality and as a commentary on the social and the political quarrels. 'Ceremonies within the play' includes music, songs, trials, weddings and funerals, as few examples. These are usually utilized to discuss cultural phenomena in a theatrical manner. Ceremonies in general produce paradoxical sentiments. They may carry happiness and harmony. They also, particularly in serious drama, produce feelings of disorientation and sadness. Hornby argues that ceremonies "contain encoded signs by which their society understands both the external world around them, and the emotional world within" (51).

'Role playing within the role' refers to characters acting out other characters, putting on the necessary identity markers which may include masks, faces, costumes, make-up, powders, and the like. Through role playing, the author is enabled to show "not only who the character is, but also what he wants to be" (67). Role playing adds up to the alienating effect of metadrama. The theatrical nature of role playing participates remarkably in the deconstruction of boundaries. Additionally, Role playing gives much space to the spectator to formulate metaperspective views on the staged experience when that experience is contrasted with that of the actual reality. 'The literary and real life references within the play' is the means through which the drama intersects, directly or indirectly, either by means of allusion or direct quoting, with real events or fictional narrative, or both. Audience's familiarity with the reference determines the degree of interaction and engagement. Citations, allegory, parody and adaptation are forms of the literary or real life references which are metadramatic.

'Self-referencing within the play' is characters/actors' way to be in dialogue with the acting roles they dramatize or with the incidents of the play itself. A character may step out of the role to address the spectators smashing the fourth wall. Self-referencing is a powerful metadramatic technique as it is very engaging and stimulating the spectators "to examine consciously what lies 
behind the play" (Fei 101). Of these five metadramatic devices, the researcher will explore Hwang's utilization of the first four: the play within the play, the literal and real life reference, the ceremonies and the role-playing within the role. The fifth one is not utilized in the plays under analysis. These devices are remarkably explicit in the theatrical fabric of the target plays and, arguably, in Hwang's deconstructivist project. Throughout the analysis, the researcher argues that Hwang's employment of the metadramatic devices in the target plays has both theatrical and social functions. Theatrically, metadrama with its layering of texts creates richness and density which open plays to multi-layered interpretations. Socially, metadrama, through its estrangement or alienating effect, destabilizes spectators, increases their conscious engagement with the staged experience and thereby urge them to reconsider their ideological positionality.

It is important to note that $M$. Butterfly, which has received several readings, is included in this study for a number of reasons. The metadramatic nature of the play, which has not been given enough attention, should prioritize the selection of the play. The play is realized as Hwang's major contribution to the 'culture war' of the time, which is a major thread in the present study. The play is also a reference point according to which the theatricality, or metatheatricality, of the second target play Bondage is measured and evaluated. Bondage develops the discussion of racial profiling and moves steps ahead of $M$. Butterfly to call for a deconstruction of all types of stereotyping, be they racial, gender, ethnic, classist or sexist. Admittedly, the space given to Bondage in the analysis is less than that given to M. Butterfly. After all, Bondage is a one-act drama. It is less theatrical and so less provocative compared to $M$. Butterfly. Yet, its inclusion in the present study serves the purpose of tracing Hwang's development of thought and theatricality while maintaining his mission of deconstructing stereotypes.

It is also worth noting that the researcher draws on the works of other scholars and researchers writing about the East-West polemic. Edward Said's Orientalism (1979), which links the construction of gendered imagery to the construction of race and the imperialist mission to colonize and dominate, informs much of the analysis. Though Said's discussion in his Orientalism does not include the far Eastern countries, namely China and Japan, his views can be applied to any colonizer-colonized discourse in which misrepresentations of the Other are triggered by conceived issues of 'positional superiority' and racial fixity.

A total theatre, $M$. Butterfly (Henceforth $M B$ ), delivers its meaning through a set of metadramatic devices, one is embedded into the other. Hwang utilizes the play 
within the play device, in this case Puccini's opera Madame Butterfly (1904), which is of the framing type. The main action of the play is controlled and developed in the light of the incidents of the opera. Inside the integrated text of Puccini's opera, Hwang incorporates a real life reference which is an espionage trial of a French diplomat and a Chinese opera singer. Ceremonies of music, songs, dancing, and the courthouse scene of the Espionage trial invade the integrated texts. Occasionally, the main characters step out of their main roles to role-play characters from the opera and from the espionage trial.

Giacomo Puccini's opera Madame Butterfly (1904) epitomizes the West/East power relations in which the West is the masculine, the more powerful, the dominant and the essential in relation to the East which is the feminine, the weaker, the dominated and the inessential. The opera dramatizes the tragic end of a fifteen-year Japanese geisha girl called Cio-Cio-San, which means 'Butterfly' in Japanese, who commits suicide over her abandonment by her American husband, Pinkerton. So attracted to Pinkerton, Butterfly rejects all Japanese suitors, abandons her ancestors and embraces her husband's Christian faith. Yet, in her wedding, Butterfly "carries with her... the knife her father used for his seppuku, or ritual suicide by disembowelment -and music foreshadows the repetition that will inevitably occur" (Kondo 8). After marriage, Pinkerton leaves for three years, marries an American woman, and sends a message to Butterfly to marry one of her Japanese relatives. Vainly waiting, Butterfly stabs herself with her father's dagger. "The opera resolves in a swelling, tragic orchestral crescendo" (Kondo 8-9). The Espionage trial, which also betrays similar gendering images about the East, dates to 1980 when the New York Times reported the trial of a French diplomat and a Chinese opera star who were sentenced to six-year imprisonment for spying for China. Mr. Bouriscot was accused of passing classified information to China after he fell in love with $\mathrm{Mr}$. Shi whom he believed for many years to be a woman.

Hwang inscribes the mistaken sexual identity of the French diplomat and his Chinese lover into the incidents of Puccini's opera. He appropriates that formula as the backdrop of his work to both highlight and subsequently deconstruct what Dorinne K. Kondo calls "the terrain written images of the 'Orient'," most specifically "the submissive oriental woman;" as Butterfly, and "the cruel white man," as the master (6). In other words, what Hwang puts forward to deconstruct through inscribing some of the incidents of Puccini's opera and the espionage trial into the dramaturgy of his play, as it will be explained, is what Edward Said refers to in his Orientalism as the Western construction of the East as feminine versus the powerful masculine West. Established as an example of a Western Orientalist text, Puccini's opera celebrates many Western-formulated stereotypes about the East. These include the emasculation of the East and its pertinent 
perception as a supine female (Butterfly) that is doomed to live, suffer and die silently and unnoticed, the romantic attachment of that 'Butterfly' to her cruel white man, the ritual death of 'Butterfly' by committing 'seppuku', and the perception of Eastern people as little things, humble, exotic and also mysterious. The opera also naturalizes the myth that the masculine West always wins over the emasculated East. In the espionage trial, Mr. Bouriscot's discovery that he has been in love with a man not a woman suggests in similar terms the Western creation and perception of the East in traditional feminine images.

This atmosphere of gender and racial confusion is also conveyed through integrating non-literary performances into the main action. The setting of the play moves from Japan to China. Elements from the Japanese 'Kabuki' ${ }^{2}$ theatre are mixed with others from Chinese Opera. When Song, for instance, makes her first appearance on the stage, she is in traditional Chinese clothes dancing to the sound of Chinese music. The music then dissolves into the love Duet of Puccini's opera. In her second appearance, she dances to that same music but dressed as 'Butterfly.' This conflation of Japanese and Chinese elements is reflective of the Western Vision that all Asians are alike and that they belong to one culture.

Within this context of confusion, and in parody of Puccini's opera, Hwang makes the characters of his drama act out the characters of Puccini's opera. In the play, Rene Gallimard is both the Mr. Bouriscot and Pinkerton; Song Liling is the Chinese opera singer Mr. Shi and the Japanese Butterfly Cio-Cio-San. The action is filtered through Gallimard's consciousness; he, in fact, assumes the role of the master of ceremonies introducing characters and action to the audience. The play's action moves freely across time and space; in present it is a Paris prison, and in recall it is Beijing from 1960 to 1970. Two dramatic movements run in parallel terms with the incidents of the opera and the espionage trial. The first dramatic movement is the allegorical relationship Between Rene Gallimard and Song Liling in which Gallimard's narrative stands for the Western attitude towards the East; that of Song, for the Eastern reaction. The second dramatic movement, which is overtly political in nature yet reflective of the false Western representations the East, and which corresponds to the implications of the opera and the espionage, is that of the American invasion of Vietnam, which was triggered by the false fantasies about the Orientals. Both narratives end up with the realization that cultural beliefs held against the Other are mistaken.

The play begins with both Song and Gallimard role-playing the gender and the racial power relations from Puccini's opera. Making use of the stage division into upstage and downstage where the up suggests power and dominance, and the down, weakness and submission; many of the Gallimard/Song scenes, which are in total subversion of the scenes in the original opera, feature Song upstage and Gallimard downstage. Song appears upstage on the elevated ramp; she is 
delineated as "a beautiful woman in traditional Chinese garb" who "dances a traditional piece from the Peking Opera" (1); Gallimard is "downstage" contemplating her. In Act Two, Scene Three, Song seeks information from Gallimard about the American intervention in Vietnam. Her privileged position as both a spy and a lover is visually indicated by placing her "upstage, watching," while Gallimard and the French ambassador are placed "downstage" discussing the subject (44). This same positioning is adopted throughout the play to reinforce Song's empowerment. The most striking example is in Act Two, Scene Six. Song informs Gallimard that she is expecting a baby from him. Gallimard's total submission to her is visually expressed by presenting him kneeling before her until the end of Scene Seven.

This positioning subverts the traditional male/female, white/non-white, and East/West cultural discourses as it suggests both Gallimard and the West's victimization by their own fantasies. Gallimard's creation of the oriental woman as a butterfly is suggested by his confinement, literally and figuratively, in a prison cell which he describes, surprisingly enough, as an "enchanted space"(2). He is also "old" and "tired" putting "a sad smile on his face" (1). The blurring of racial and gender boundaries is aurally suggested by the fusion of Western and Chinese music; the Chinese opera music "dissolves into a Western opera, the 'Love Duet' from Puccini's Madama Butterfly" (1). In their first encounter at the German ambassador's house where Song role-plays the final death scene of 'Butterfly,' Gallimard, emulating Pinkerton, is so moved by her acting skills:

Gallimard: ... You were utterly convincing. It's the first time Song: Convincing? As a Japanese woman? The Japanese used hundreds of our people for medical experiments during the war, you know. But I gather such an irony is lost on you.

Gallimard: No! I was about to say, it's the first time I've seen the beauty of the story.

Song: It's one of your favourite fantasies, isn't it? The submissive Oriental woman and the cruel white man. (17)

The scene betrays the claim that gender and race are mere performative acts. Hwang's employs the cross-dressing technique as part of the role play through which the actor is enabled to distance himself from the role he or she plays. This in turn helps in the "re/presentation of that role as a construct" (Aston and Savona 35). The Chinese Song, whose identity as male is known to the audience ${ }^{3}$, is able through make-up and change of costume to pass as a convincing delicate Japanese woman, the "perfect woman" as Gallimard ecstatically muses (4). As a representative of Western culture misinterpretation of the Other, Gallimard fails 
to distinguish Song Liling the actor playing a Japanese 'Butterfly' from Song Liling the Chinese person. Driven and deluded by a heavy heritage of racism, sexism and imperialism as manifestations of attempts to degrade the other, Gallimard "castrates Song" (Eng.151) to make him/her match his vision of the objectified Orientals. Gallimard dreams of "slender women in chong sams and kimonos who die for the love of unworthy foreign devils. Who are born and raised to be the perfect women. Who take whatever punishment we give them, and bounce back, strengthened by love, unconditionally" (91).

Gallimard, like Puccini's hero, mistakes Song Liling for 'Butterfly.' Dorinne K. Kondo observes that Gallimard "assumes a transparent relationship between outer appearance and the inner truth of the self. The signs of this identity are clothing and make up, and since Song is dressed as a woman, Gallimard never doubts Song's essential 'femininity'"(15). Assuming, at times, the voice of the dramatist in his mission to dispel stereotypes, Song revolts against this image of the Oriental woman as a 'Butterfly,' and implicitly against the feminization of the East. She explicitly attributes the Westerner's love of Puccini's opera to their unjustified racial and sexist prejudice:

Song: Consider it this way: what would you say if a blonde homecoming queen fell in love with a short Japanese businessman? He treats her cruelly, then goes home for three years, during which time she prays to his picture and turns down marriage from a young Kennedy. Then when she learns he has remarried, she kills herself. Now, I believe you would consider this girl to be a deranged idiot, correct? But because it's an Oriental who kills herself for a westerner - ah! - you find it beautiful. (17)

To put it differently, Song rebels against what s/he comes to call later "the international rape mentality towards the East," that mentality which perceives the East as a promiscuous woman whose "mouth says no, but her eyes say yes" (82-3).

Considered as "a cynosure for cultural debate on race and sexuality" (Shin 178), $M B$ raises questions about the passivity and complicity of the East which, in its relationship with the dominant masculine West, reproduces "images of the delicate, the dainty, the subservient, the polite and the apologetic" (Deeney 27). In an interview with John Louis DiGaetani, Hwang points out:

The play is fairly even-handed in saying that the East also misperceives the West. The East is guilty or complicit in this dual form of cultural stereotyping. The West, having had the advantage of being the colonial 
power of the two over the past couple of hundred years, has an attitude of condescension toward the East. But the East has played up to that to its short-term advantage without thinking of the long-term ill effects that reinforcing those racial stereotypes causes. (141)

In performance of this complicity, Song Liling role-plays the stereotypical feminine inferiority versus the masculine superiority of the West. Allegorically, she allows imperialist Gallimard to cross racial and gender boundaries by inviting and entertaining him at her parlor. In front of him, Song plays out the appropriate submission, modesty and docility. She passionately listens to him. She does not even find herself equal to Western women; and, to his satisfaction and male exaltation, she declares herself his 'Butterfly.' Deluded by this performative behavior of submission to a Westerner, Gallimard feeds in information about the Vietnamese who, as Orientals, "want the good things we can give them," and who "will always submit to a greater force" (46).

The nature of race and gender as mere social constructs is further communicated through creating the contrast between Gallimard's sexual relationship with Song, the 'Oriental' woman, and his other relationships with three Western women: the school girl with whom he first experienced sex, his wife Helga and the Danish girl, ironically named Renee. With Song's playing the oriental femininity, Gallimard, as a man, takes the initiative in trespassing the limits of gender space. His penetration into her apartment is reflective of both the phallic power and the positional superiority he is to occupy as a white man. Yet, Gallimard's relationships with the school girl, his wife and Renee subvert and conflate these racial and gender boundaries.

Acting out the ideals of independence and domination claimed by the feminist movements in the $1960 \mathrm{~s}^{4}$, the school girl assumes the superior (traditionally masculine) position in her sexual relationship with Gallimard:

Gallimard: You told me to wait in the bushes by the cafeteria that night. The next thing I knew, she was on me. Dress up in the air....

Marc: She loved the superior position. A girl ahead of her time.

Gallimard: I looked up. And there was this woman ... bouncing up and down on my loins. (32)

As Gallimard is astounded by the school girl's bluntness, he is equally humiliated by the openness of the Danish Girl Renee, whose name is pronounced the same as Gallimard's first name, Rene- a further suggestion of gender confusion. The similarity between Renee and the school girl is dramatized; the two characters are played by one actress. Renee, like the school girl, is sexually 
bold and uninhibited; she appears totally naked in front of Gallimard, and the audience. She is also outspoken, and "too willing, so as to seem almost too . . . masculine" (54). Renee feminizes Gallimard, shocking him into a realization of the smallness of his genitals thereby destabilizing all discourse about the relevant phallic dominance:

Renee: I guess. But, like, it just hangs there. This little . . flap of flesh. And there's so much fuss that we make about it. Like, I think the reason we fight wars is because we wear clothes. Because no one knows between the men, I mean - who has the bigger . . . wennie. So, if I'm a guy with a small one, I'm going to build a really big building or take over a really big piece of land or write a really long book so the other men don't know, right? (55)

The binaries of the West and the East and the relevant masculine/feminine are vehemently interrogated through the main characters' identification with the characters of Puccini's opera. In emulation of Pinkerton's desertion of Butterfly as a means of gaining more power over her, Gallimard's relationship with Renee, his "first extra-extramarital relationship" (54), is similarly meant to assert his manliness over Song. Gallimard fantasizes "what would she say if he were unfaithful ... nothing. She would cry, alone, into those wildly soft sleeves ... It was her tears and her silence that excited me, every time I visit Renee" (56). The mistaken nature of this belief is signaled by Gallimard's downfall both in his career and in his relationship with Song. His views about the submissive Vietnamese in front of the powerful Americans prove false. Many Americans were killed by the Vietnamese. In consequence, Gallimard is driven out of office and is ordered back home. Correspondingly, Gallimard's stereotypical views about the helplessness of oriental women before the white male's power collapse. Visually imparted, Song appears "up center"; she "begins to dance with the flowers . . . a drunken dance, where she breaks small pieces off the stems" (56). Song's cutting the flowers off their stems suggests her ensuing castration of Gallimard. Against Gallimard's fantasy creation of her, Song decides to transform into her true gender identity as a man.

Gallimard: You have to do what I say! I'm conjuring you up in my mind! Song: Rene, I've never done what you've said. Why should it be different in your mind? Now split - the story moves on, and I must change. (78)

The male/female strict boundaries do dismantle as Song decides to undress to reveal her sex reality. "The construction of Song-as-female," Shimakawa 
explains, "was enacted by manipulating and obscuring sight - by maintaining the hidden spaces beneath clothing - and the destruction of discrete space, consequently, is enacted when those hidden spaces are revealed to view" (351). Gallimard who is unwilling to see Song naked to maintain the man-woman defined space is now invaded, literally and figuratively, by the male Song transgressing all defined gender distinctions. Unable to break up with his fantasy creation of her as the epitome of Oriental 'Butterfly,' Gallimard transforms into Puccini's Oriental protagonist. The sight of Song's male sexual organ amounts to a visual destruction of Gallimard's sense of defined space. Song does not only deny Gallimard's authorial control over her, but also sets out to share him his male space. The stunning obscenity and shocking revelation of the scene account for Gallimard's disgusting response, "Now get out! I have a date with my Butterfly and I don't want your body polluting the room" (90). Robert Skloot reasons: "Hwang's point [is] that what we assume about gender depends on what we see, or don't see, then what is finally obscene to Gallimard is the visual proof that those assumptions can no longer be made" (63).

The deconstruction of all racial and gender stereotypical boundaries is orchestrated in the play's final stage picture in which Song and Gallimard roleplay the trial scene of the French diplomat and the Chinese opera singer. The relevant mistaken gender identity of Mr. Bouriscot and Mr. Shi intersects with that of the assumed relationship between the West and the East. As Mr. Bouriscot is victimized by his own fantasies about his oriental partner, so must be both Gallimard and, by extension, the West. Upon the unveiling of their espionage, Song and Gallimard are taken to the courthouse wherein Song ironically moves and acts in accordance with the stereotypical image of maleness; Gallimard appears "as sorry . . . as a Butterfly" (91). The signs of Song's newly acquired identity are the conventional masculine attire (the Armani suit); "the confident stance, with feet planted wide apart, arms akimbo; a deeper voice; a defiant, cocky manner as he strides back and force on stage, surveying the audience" (Kondo 24). Gallimard, on the other hand, assumes the role of the 'Butterfly.' He has his face painted with the geisha-like (Japanese) make up. He puts on Song's wig and Kimono, the traditional attire of 'Butterfly'; he also holds a knife. Theatrically speaking, the scene is total subversion of Puccini's opera in which the miserable 'Butterfly' finally commits suicide over her white lover's cruel desertion of her. It is worth noting that the scene is shrouded with The Death Scene music from Puccini's opera anticipating the death of the newly constructed 'Monsieur Butterfly'. Gallimard "sets himself center stage, in a seppuku position.... He sets the tip of the knife against his body" pronouncing his inevitable transformation, "My name is Rene Gallimard - also known as Madame Butterfly". Gallimard, in a "radically disturbing" closure, collapses to 
the floor in a similar way to Butterfly's in Puccini's opera (Kondo 20). Strong lights move on the exalted Song who "smokes a cigarette; the smoke filters up through the lights. Two words leave his lips. Butterfly? Butterfly? Smoke rises as lights fade slowly to black (92-3).

The deconstructing power of the image lies in the irony that, through skilful performance, Song can simultaneously pass as the epitome of 'the Perfect woman' and also as the full representation of manhood. The image thus shatters to pieces the imperialistic claim that "an oriental can never be completely a man" (83). The performance specificities of characters in that image also suggest the re-arrangement of the gender and racial power relations. Song, the representative of the so-claimed objectified Orientals, "stands as a man" refusing to be placed within strict boundaries as an act of subordination (93). Enjy Ashour explains that in the light of this process of role reversal, the play underscores the argument that the orientalist discourse "is not fixed, eternal, non-negotiable; [in fact], it could be questioned, redefined and reshaped" (61). Hwang's Bondage, a dense, relatively less theatrical, one-act play, de-naturalizes all notions about the fixity of racial and gender identities. In fact, the play could be deemed an extension of $M B$ as it continues to explore cultural and historical clichés about races. The play also reconstructs some of the most dramatic scenes of $M B$ as a way of enforcing their thematic implications. The confrontation scenes, for instance, between Song Liling and Rene Gallimard in $M B$ are subtly reproduced in Bondage in which the main characters, Terri and Mark, simultaneously debate both their desire for each other, and the cultural, in this case racial, politics entangled in that desire. The metadramatic device of role playing within the role is the fundamental theatrical strategy through which the two characters get involved in a series of verbal swordfights on issues of race and ethnicity paving the way for the final consummation of their desire.

While Hwang, in $M B$, falls into the trap of committing the sin which he condemns by cynically and ironically making Gallimard transform into a 'Butterfly,' in Bondage, he destabilizes all prejudices calling for a "color-blind utopia" in which people may encounter one another as human beings stripped of all extrinsic biases (Sun and Fei 121). Through a set of role-playing in which the main characters act out racialized subjects, Hwang raises questions about the validity of ethnic identities concluding with the statement that all race is performative, that the skin colour is a poor signifier of one's true identity and that only through means of love and equality can communication among people take place. Set in a sadomasochism parlor on the outskirts of Los Angeles, the play features Terri, a dominatrix who, the stage directions indicate, "paces with her whip in hand" in front of her longtime willing submissive Mark, identifiable only as a man "who is chained to the wall". Terri and Mark are clad from head 
to toe; "their faces, are covered by full face masks and hoods to disguise their identities" (23). ${ }^{5}$ Nothing else is known about the two characters except the implication of the setting that the two characters will be involved in some sexual games role-playing the dominant and the dominated. During these games, each character role-plays different racial identities according to which his/her power position to the other partner is negotiated. One may argue that these different racial identities played by the characters demonstrate the ideology which defines the relationship between the dominant culture and the minority subject.

The role playing in the beginning of the drama is a demonstration of the performative and the artificial nature of race:

Mark: What am I today?

Terri: Today- you're a man. A Chinese man. But don't bother with that accent crap. I find it demeaning.

Mark: A Chinese man. All right. And who are you?

Terri: Me? I'm- I'm a blonde woman. Can you remember that?

Mark: I feel very vulnerable.

Terri: You should. I pick these roles for a reason, you know.(She unchains him.) We'll call you Wong. Mark Wong. And me - I'm Tifanny Walker. (23)

By locating race in the realm of role playing, Hwang capitalizes on the fact that race "is not fixed, organic, and biological, but capable of being negotiated, redefined and impersonated, ... an enactment under pressure from the dominant culture" (Park 46-7). The racial identity of a person is thus as theatrical as the costume that the actor puts on; it is like that piece of on-stage prop which generates meaning only in relation to the other elements at play.

That first scenario which Terri and Mark role-play is therefore an enactment of notions of racial fantasies and stereotypes. Terri's assignment of Chinese-ness to Mark constitutes for him an act of personal degradation and humiliation. On one level, the act is reflective of the dominant culture emasculation of Chinese men. Terri, as a Caucasian, voices that view:

Terri: I've seen you looking at me. From behind the windows of yourengineering laboratory. Behind your-horn rimmed glasses. Why don't you come right out and try to pick me up? Whisper something offensive into my ear. Or aren't you man enough? (23)

Terri's emasculation of Mark reproduces the various layers of historical and institutional power practiced by the dominant culture over the marginalized 
subjects. The act, Samuel Park argues, evokes "the anti miscegenation laws during the early part of the $20^{\text {th }}$ century, as well as a contemporary Western fear and dislike of East Asian nations such as Japan (and now India and China) in their competition in the field of technology" (50).

The act of assigning Chinese-ness to Mark, and Caucasian-ness to Terry is also a performance of the dominated-dominant relationship. Mark's desire to express his love for Terri is barred by the fact "you're a blonde. I'm Chinese. It's not so easy to know whether it's OK for me to love you" (23). Terri does not only enforce that vision: "It's not real likely I'm gonna love you... I'm a normal girl. With regular ideas. Regular for a blonde, of course" (24), but also brings up another racial prejudice against Chinese-American, namely their bookishness and their strong familial bond. Terri elaborates:

I would never be prejudiced against an Oriental. They have such ... strong family structures ... hard working ... they hit the books with real gusto ... makes my mother green with envy. But, I guess ... how excited can I get about a boy who fulfills my mother's fantasies?" (24)

Terri's stereotypical recognition of Asian-Americans as studious and attached to their mothers is meant to feminize the race. In finding Mark strongly associated to his mother, Terri projects onto him the Oedipal complex, that is a person who is unable to maintain his masculinity and live independently away from his mother. Similarly, bookishness in the dominant culture imagination is a pop culture trope which stands for effeminacy. The Asian-American man is not manly enough to get a blonde without force and without the help of other fellow men. Terri sarcastically states, "What are you going to do now? Rape me? With your friends? ... it still requires more than one of you to get the job done" (28). These stereotypical performances of Asian American maleness are to be viewed in conjunction with the long history of exclusion practiced over racialized subjects. In her Immigrant Acts, Lisa Lowe reveals that the Asian-American subject was not only legally barred from citizenship but also from masculinity itself which was only assigned to the white people (5). Terri, thus, evokes this legacy of emasculation and feminization, "limiting Mark's performative choices to only those remembered from hegemonic practices"(Park 58).

It is important here to spot the huge gap between the vision of the dominant culture and that of the Asian-American. The so-called negative stereotypes about the Asian-Americans as hard working in their studies and as committed to their families are not, for many Asian-American communities, negative aspects at all. They are, paradoxically enough, both aspirational and inspirational models which many people strive to emulate. Park argues that while the Asian- 
American student who does well in his studies to get the highest marks is sarcastically tagged as 'nerdy' by the dominant culture, his ethnic community "valorizes" him by making him the object of attention and care. Park also argues that the demonizing of these qualities by the dominant culture is ingrained in the racial assumption that Asian-Americans excel in Math and science not due to any inherently genuine "love of science or quantitative reasoning," but due to their "need to move toward economically-rewarding professions" to protect themselves (56).

Terri continues her humiliation and abasement of Mark denying him any positive performance to play. Asian-Americans, Terri suggests, have no flattering role models; they are to remain the weaker partner in the sexual coitus, always dominated and never dominant. This is verbally and visually suggested in the following foreplay:

Mark: How about Bruce Lee? Would you find me sexy if I was Bruce Lee?

Terri: You mean, like, 'Hiiii-ya! I wuv you.' (Pause.) Any other ideas? Or do you admit no woman could love you, Mark Wong (Mark assumes a doggy position.)

Mark: I'm defeated. I'm humiliated. I'm whipped to the bone. (29)

The implication here is that even those seemingly positive Asian American role models are rejected and ignored by the dominant culture as they are unable to introduce new, unexpected models other than those planted in the popular consciousness. Brecht's concept of the "alienation effect" can be cited here as an explanation of the continuous exclusion of racialized subjects by the dominant culture (Brecht 192). Because those racialized subjects often present familiar performances on the stage of every day life, they consequently get rejected; this is like the audience's rejection of the stock character in the badly-written dramas.

Deconstructing all ideological notions about the stability of racial codes, Hwang, theatrically, makes the same characters of his play role-play other racial identities. This is understood, in the logic of this research, as an enforcement of Hwang's call for the rootlessness of all racial profiling. Terri and Mark play out another racial game in which Terri is an African-American woman and Mark, a Caucasian. By the logic of the dominant culture and the nature of role-playing which always evolves, Mark is moving from low to high, while Terri, from high to low. As a white person, Mark exercises a positional superiority over the inferior black-skinned Terri. Mark painfully reminds Terri of the long history of abuse and ill-treatment that the African-American woman has gone through: 
Mark: ... And the dilemma I know you're facing. Your own men, they take you for granted, don't they? I think you should be a little more open-minded, unless you wanna end up like the $40 \%$ of black women over 30 who're never gonna get married in their lifetimes. (Silence.) (32)

By reminding Terri of her low place within the hierarchy of desire, by tagging her "sensuous,"(32) and by shaming her for being deserted by her "African American brothers" (31) who prefer to date white women, Mark is humiliating and intimidating her to accept him as the dominant, more powerful partner. Terri lashes back evoking the white liberals' hypocrisy who claim they are attracted to black woman's intelligence while in fact they are after her "tight outfit" which is "slinky," and her "lips which are full and round - without the aid of collagen" (32). In a suggestive visual image, the game ends with Terri mounting the submissive Mark:

Terri: On your knees, Liberal! (She runs the heel of her boot over the length of his body.) You wanted to have a little fun, didn't you? With a wild dark woman whose passions drown out all her inhibitions. (She pushes him onto his back, puts the heel to his lips.) I'll give you passions. Here's your passion ... suck it. Like the lily-white baby you boy you are (Mark fellates her heel). (33)

Wrapped in issues of racial profiling, the relationship between Mark, the white, and Terri, the African American, fails. The issue becomes more complicated to the extent that Mark and Terri, as Asian subjects in their third session game, can not solve the problem of personal alienation. Enacting the dilemma of what Edward Said defines as racialized subjects' internalization of the racial discourse, Mark and Terri, though now of the same race, are prejudiced against each other. As an Asian-American, that is a man of race, Mark is selfloathing, and will always be longing for a union with a white woman to assuage the pains of racial differences and to rid himself of what Ann Anlin Cheng calls "the melancholy of race." ${ }^{6}$ The union between two Asian-Americans, following the reasoning of Cheng, will only compound the problem of the "racial grief." Still, a relationship with a white woman is masochistic in nature; Mark is to be always reminded that he is less and that he "is missing the 'correct' genes" The chance of a successful union like that hinges on the white woman's acceptance of merging identities. Only then can Mark's "hidden grief" be healed. The fact remains that this might also fail (qtd.in Park 67).

The Asian American Terri, on the other hand, does not accept a relationship with a fellow Asian American man. Ironically, she projects onto Mark all the 
stereotypical prejudices against Asian-American men. For her, they are abusive and of a low origin:

Terri: Asian men. (Pause.) Asian men who just assume because we shared space in a genetic pond millions of years ago that I'm suddenly their property when I walk into a room. Or an office. (Pause.) Now get this straight. I'm not interested in you, OK? In fact, I'm generally not attracted to Asian men.... I just don't date them as a species. (35)

Just as the dominant culture emasculates Asian subjects, so does Terri: "you're looking for someone who reminds you of your mothers. Who'll smile at the lousiest jokes and spoon rice into your bowl while you just sit and grunt" (36). Though of the same race, Mark and Terri fail also to achieve true bondage.

By limiting the performance choices that both Mark and Terri, as persons of color, are to play, Hwang suggests that even the freedom to enact race is tied with the cultural legacy of the past. Terri does not accept the Asian Mark as he, in his attachment to his mother, will possibly remind her of her abusive father; she does not also accept the white Mark as he, in his unmanly behavior, will most probably remind her of her black father. This cultural crisis, as Terri explains, is rooted in the belief that "cultures have pasts that eventually catch up with them. For instance, white Americans were evil enough to bring Africans here in chains - now, they should pay for that legacy. Similarly, Asian men have oppressed their women for centuries. Now they're paying for their crime" (36). In other words, to suggest that racialized subjects are the victim of conspiracy is not only to miss the point but also to hide the truth. The problem is that these negative stereotypical performances did exist at some point in time and that due to their reenactments and reiterations by those specific persons, they turned into entrapping defining features or clichés.

Echoing Hwang's voice, and possibly that of the audience, Mark raises the rhetorical question, "Why should my love life suffer for crimes I didn't commit? I'm an American!" (36). The answer is theatrically given through Mark and Terri's stripping themselves of all racial masks; they move beyond the world of fantasy or pretense to encounter each other in the realm of the real, as human beings. Mark then declares:

it feels like all labels have to be re-written, all assumptions re-examined, all associations re-defined. The rules that governed behavior in the last era are crumbling, but those of the time to come have yet to be rewritten. (445) 
Racial categorization is thus a barrier to true communication. Giving up this categorization would mean a denial of the networks of power contained within it. When Mark and Terri free themselves from the bondage of race and gender and the power positioning involved, they find love, the true 'bondage' that should exist among human beings. Mark and Terri, the stage directions indicate, "cross the stage towards one another ... Mark touches her hair. They gaze at each other's faces, as lights fade to black" (46).

Through the metadramatic devices of 'the play within the play', 'the literal and the real life reference,' 'the ceremonies with the main text' and 'the role-playing with the role,' David Henry Hwang deconstructs the culturally constructed stereotypes about minority subjects in America, particularly those of Asian descent. The metadramatic devices, as the analysis has shown, create a type of aesthetics by which the audience is stimulated, through the relevant 'estrangement effect,' to reconsider the ideological significance of the on-stage experience. In other words. The 'alienation effect' produced by the metadramatic devices deprive the audience from any sense of comfortable identification with the action or the characters. The mimetic illusion on the stage is broken down, and the dislocated spectator is, consciously or unconsciously, granted a meta-perspective on his/her ideological positioning.

In Shakespeare's Hamlet, 'the play within the play' theatrical strategy is meant to catch the conscience of the king. Similarly, in Hwang's M. Butterfly and Bondage, the intricate web of the metadramtic devices, namely the play within the play, the intersection with real life event, the ceremonies of music, songs, dances and the courthouse scene, and the role-playing within the role, all interact to catch the conscience of the audience. $M$. Butterfly deconstructs racial and gender stereotyping through deconstructing the original orientalist message of Puccini's opera Madama Butterfly, the mediating text, and through the reproduction of an actual event of the espionage trial of the French diplomat and his Chinese opera singer in which the mistaken gender identity of the concerned parties is the root of the problem. As in a palimpsest, the two texts are reworked and rewritten in the light of Hwang's de-constructivist mission. The myth of the East as the feminine in its relationship with the West as the masculine is broken down as Hwang deliberately subverts the Song/Gallimard power relations. Throughout the play, Gallimard is delineated as a victim of his fantasies and of his fictional creation of the Orient and the Orientals to awaken to the fact that his lover has been a man disguised as a woman. Gallimard transforms into a Butterfly, a further indication of the arbitrariness of stereotyping. The racial and 
gender differences are thus reduced to the mere sphere of theatrical performance which is affected and unnatural. Sadly, as his characters perform the smashing of the Orientalist discourse, Hwang falls into the trap of creating a new, similarly disfigured, hegemony in which the West, impersonated by Gallimard, is reconstructed in the pathetic image of the 'Butterfly' while the East, acted by Song, puts on a cartoonish and dragon-like mask of masculinity and power. The clash is still there.

Through role-playing within the role, Bondage moves from the clashing color-strict relationships to relationships devoid of any relevant racial or gender biases. That project is achieved through making the two masochistic characters, Terri and Mark, role-play several racial identities and get involved in a giveand-take dialogue about stereotypes and power relations. The power of roleplaying is used to suggest the groundlessness of such racial traits and the denial of any fixed notion of identity which is as theatrical as the various roles played out by the one actor. The racial shifts Mark and Terri enact allow them to "expose stereotypes associated with a particular race, revealing to the audience the arbitrary nature of the supposedly innate racial traits; blondes as bimbos, Asians as geeks, and African Americans as sexual beasts exist only in the realm of pretend" (Gildmark). Furthermore, these racial identities draw participants into a series of power relations which in turn block all attempts at humanist communication and intimacy. Once these racial masks are given up, as suggested by Terri and Mark's theatrical disrobing, love, which is the strongest race-free bondage, is to be found.

\section{Endnotes}

${ }^{1}$ Henceforth all references to the text are from the 1989 Plume edition, incorporated hereafter parenthetically in the text.

${ }^{2}$ In that theatre, men play women's roles as the latter were forbidden to appear on stage. Cross-dressing was used to achieve that effect.

${ }^{3}$ In his "Author's Notes," Hwang states that the audience must believe that Gallimard was seduced by a man disguised as a woman.

${ }^{4}$ The perception of the East in the stereotypical feminine terms of submission, obedience and modesty has been stimulated by cultural and political circumstances. Toril Moi explains that the feminist movements in the 1960s produced independent women claiming their political and social rights and rebelling against the traditional image of the domesticated female (20). In effect, the Western patriarchal society started to look for its missing idol of the perfect woman. Exotic, mysterious, knowable in the sense used by Edward Said, and still far from the feminist thinking, Asian/ Oriental 
women were found to be the substitutes. Another important factor which contributed to the cultural production of the East in feminine terms is that many Eastern countries, in the early decades of the twentieth century, fell under the colonization of the West. The west, in effect, started to think of itself as masculine, "big guns, big industry, big money - so the East is feminine - weak, delicate, poor" (M. Butterfly 83). Robert K. Martin comments: "The East becomes the measure by which one recognizes one's Westernness, just as the feminine becomes the means by which the man recognizes his masculinity" (101). This accounts for Gallimard's inability to distinguish between Song's rectum and a woman's vagina, though the relationship lasted for more than twenty years.

${ }^{5}$ Henceforth all references to the text are from 1996 Dramatists Play Service Inc. edition, incorporated hereafter parenthetically in the text

${ }^{6}$ This is the title of Cheng's book in which she presents an insightful analysis of the relationship between race and psychoanalytic theory. Cheng finds out that when racialized subjects realize that they are not like the white Others around them, they start to experience feelings of "hidden grief" over the loss of that "perfect self." This very feeling leads to continuous longing for re-unity with that lost ideal for the sake of healing psychic wounds. In Bondage, Mark, the racialized subject, is dramatized in constant pursuit of Terri, the white woman and the incarnation of his lost ideal or perfect self.

\section{Works Cited}

Aston, Elaine and George Savona. Theatre as Sign-System: A Semiotics of Text and Performance. London and New York: Routledge, 1991.

Bonnie, Lyonns. " 'Making His Muscles Work for Himself': An Interview with David Henry Hwang." Literary Review 42 .2 (Winter, 1999): 230-44. Brecht, Bertolt. "A Short Organum for the Theatre", Brecht on Theatre: The Development of an Aesthetic. Trans. John Willet. New York: Hill \& Wang, 1964.

Butler, Judith. "Performative Acts and Gender Constitution: An Essay in Phenomenology and Feminist Theory:" Performing Feminisms: Feminist Critical Theory and Theatre. Ed. Sue-Ellen Case. Baltimore: John Hopkins UP, 1990.

Cheng, Ann Anlin. The Melancholy of Race: Psychoanalysis, Assimilation, and Hidden Grief. New York: OUP, 2001.

Deeney, John J. "Of Monkeys and Butterflies: Transformation in M. H. Kingston's Tripmaster Monkey and D.H. Hwang's M. Butterfly." MELUS 18.4 (Winter, 1993): 21-39.

DiGaetani, John Louis. "An Interview with David Henry Hwang." The Drama Review 33. 3 (Fall, 1989):141-53. 
Eng, David L. Racial Castration: Managing Masculinity in Asian America.

Durham: Duke UP, 2001.

Esmail, Enjy Ashour. 'Negotiating Asian-Americans' Image in David Henry Hwang's M. Butterfly, Bondage, F.O.B and Philip Kan Gotanda's Yankee Dawg You Die, Fish Head Soup, Sisters Matsumoto. Diss. Minia University, 2013.

Fei, Liang. "Metadrama and Themes in Stoppard's Rosecrantz and Guildenstern Are Dead." Canadian Social Science 3.3 (June2007) 99-105.

Gidmark, Jill B. "Bondage:" Magill's Survey of American Literature. Salem Press, 2007. Retrieved online on 30 ${ }^{\text {th }}$ October, 2017. http://www.enotes.com/bondage-salem/bondage

Hornby, Richard. Drama, Metadrama, and Perception. Associated University Press, 1986.

Hwang, David Henry. Afterword. M. Butterfly. By Hwang. London and New York: Plume Book, 1989. 94-100.

----. M. Butterfly. London and New York: Plume Book, 1989.

-----. Trying to Find Chinatown and Bondage. Dramatists Play Service, 1996.

Kondo, Dorinne K. " 'M. Butterfly': Orientalism, Gender, and a Critique of Essentialist Identity." Cultural Critique 16 (Autumn, 1999): 5-29.

Lowe, Lisa. Immigrant Acts: On Asian American Cultural Politics. Durham: Duke University Press, 1996.

Martin. Robert K. "Gender, Race, and the Colonial Body: Carson McCullers's Filipino Boy, and David Henry Hwang's Chinese Woman." Canadian Review of American Studies 23.1 (Fall, 1999): 95-107.

Moi, Toril. Sexual/Textual Politics. New York: Routledge, 1985. Moy, James S. "David Henry Hwang's 'M. Butterfly' and Philip Kan Gotanda's 'Yankee Dawg You Die': Repositioning Chinese American Marginality on the American Stage." Theatre Journal 42. 1 (March 1990): 48-56.

Park, Samuel. The Performance of Race in Asian American Drama. Diss., University of Southern California, Faculty of Graduate School, 2006.

Said, Edward. Orientalism. New York: Vintage, 1979.

Shimakawa, Karen. " 'Who's to Say?' or, Making Space for Gender and Ethnicity in M. Butterfly." Theatre Journal 45.3 (October, 1993): 349-362.

Shin, Andrew. "Projected Bodies in David Henry Hwang's M. Butterfly and Golden Gate." MELUS 27. 1 (Spring, 2002): 177-197

Skloot, Robert. "Breaking the Butterfly: The Politics of David Henry Hwang." Modern Drama 33 (1990): 59-66.

Sun, William H. and Faye C. Fei. "Masks or faces Re-visited: A Study of Four Theatrical Works Concerning Cultural Identity." TDR 38.4 (Winter, 1994): 120-132.

Trudeau, Lawrence J., ed. Drama Criticism. Vol. 4, London: Gale Research, 1994. 